\title{
Phytoplankton trapped within seagrass (Posidonia oceanica) sediments are a nitrogen source: An in situ isotope labeling experiment
}

\section{Cristina Barrón ${ }^{1}$}

IMEDEA (CSIC-UIB), Grupo de Oceanografía Interdisciplinar, C/ Miquel Marqués 21, 07190 Esporles (Islas Baleares), Spain

\section{Jack J. Middelburg}

Netherlands Institute of Ecology (NIOO-KNAW), Centre for Estuarine and Marine Ecology, P.O. Box 140, 4400 AC Yerseke, The Netherlands

\section{Carlos M. Duarte}

IMEDEA (CSIC-UIB), Grupo de Oceanografía Interdisciplinar, C/ Miquel Marqués 21, 07190 Esporles (Islas Baleares), Spain

\begin{abstract}
We examined the retention of nitrogen associated with sedimented planktonic material trapped within a Mediterranean seagrass (Posidonia oceanica) meadow with the use of ${ }^{15} \mathrm{~N}$-enriched algal material injected into vegetated and nonvegetated sediment as a tracer. The retention of labeled nitrogen material in the sediment and the appearance in $P$. oceanica leaves, rhizomes, and roots was examined 3, 5, 9, and $21 \mathrm{~d}$ after injection. More than $80 \%$ of the label material added to the bare sediment was lost within $5 \mathrm{~d}$. Labeled material was retained better in vegetated sediments. Labeled material from the sediment was taken up rapidly by the roots, translocated through the rhizomes, and accumulated in the new leaves. The amount of ${ }^{15} \mathrm{~N}$ recovered during the experiment in $P$. oceanica meadow was fourfold higher than that recovered in unvegetated sediment, demonstrating that the $P$. oceanica meadow was more efficient in retaining the nitrogen deposited as algal material than unvegetated sediments. Enhanced trapping of sestonic particles by seagrass canopies can be an efficient nutrient acquisition strategy in the oligotrophic environments that seagrasses inhabit.
\end{abstract}

Seagrass meadows are highly productive coastal communities (Duarte and Chiscano 1999; Hemminga and Duarte 2000), producing excess organic carbon relative to community requirements (Duarte and Cebrián 1996; Gattuso et al. 1998; Hemminga and Duarte 2000), which is either exported to other ecosystems or buried in the sediments (Duarte and Cebrián 1996; Duarte et al. 2005). Export and burial also represent nutrient losses, so maintenance of the high production of seagrasses requires external nutrient inputs (Alcoverro et al. 1997). Yet, seagrass meadows often develop in nutrient-poor waters, usually resulting in nutrient-limited seagrass growth (Duarte 1995), which requires the capacity for high nutrient uptake and the ability to conserve nutrients (Borum et al. 1989; Hemminga et al. 1991).

${ }^{1}$ Corresponding author (ieacbe@uib.es).

\section{Acknowledgments}

We thank R. Martínez, N. Navarro, S. Ruiz, N. Cantero, R. Santiago, M. Calleja, J. C. Alonso, P. van Rijswijk, and J. Nieuwenhuize for field, logistic, and laboratory support and two anonymous reviewers for constructive feedback. We also thank P. Togeskov from Danisco Flexible, Denmark, for providing the plastic film used for the benthic chambers.

This work was funded by the European Commission (EUROTROPH project, contract EVK3-CT-2000-00040), cofunded by the Spanish National Plan of RTD. C.B. was supported by a scholarship from the government of the Balearic Islands.

This is publication 3734 of the Netherlands Institute of Ecology.
Seagrasses that live in environments with low nutrient concentrations are able to obtain nutrients from the surrounding water by the leaves as well as by the roots (Hemminga et al. 1991; Lee and Dunton 1999). For instance, eelgrass takes up ammonium (Short and McRoy 1984) and phosphorus (Brix and Lyngby 1985) through leaves and roots. Although seagrasses cannot increase nutrient concentrations in the water column, their canopies have a remarkable capacity to trap suspended materials and increase sedimentation rates relative to adjacent unvegetated sediments (e.g., Agawin and Duarte 2002). These trapped particles could be a potential nutrient source (Kemp et al. 1984; Evrard et al. 2005).

Posidonia oceanica is the dominant seagrass species in the Mediterranean Sea and grows under particularly low nutrient concentrations in the Balearic Islands, where it is often nutrient depleted (e.g., Holmer et al. 2003). P. oceanica develops canopies with high leaf biomass (Duarte and Chiscano 1999) that are enriched in seston (Duarte et al. 1999). P. oceanica meadows promote sedimentation rates by enhancing the sediment deposition and reducing particulate matter resuspension, leading to a stabilization of their sediments (Gacia et al. 1999; Terrados and Duarte 2000; Gacia and Duarte 2001). The water flow between the leaves of the canopy of $P$. oceanica is reduced (Gacia et al. 1999), and this leads to an enrichment in particulate organic carbon, nitrogen, and phosphorus relative to the overlying waters (Duarte et al. 1999). This deposition of organic matter within the $P$. oceanica canopy could be 


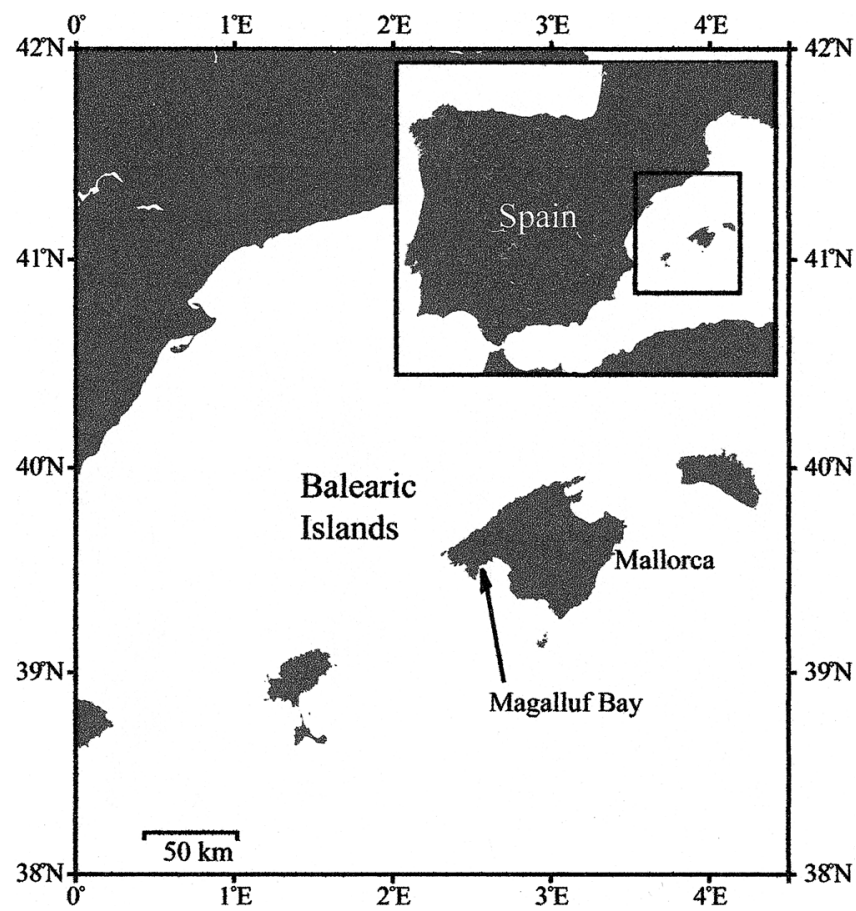

Fig. 1. Map of the study site. Magalluf Bay, Mallorca, Spain.

a nutrient supply pathway providing an important fraction of seagrass demands, thereby contributing to the maintenance of productivity (Gacia et al. 2002). However, the availability and use of this nutrient source depends on the capacity of seagrass to retain remineralized nutrients before these diffuse out to the water column - a capacity that has not yet been assessed.

Here, we test, through an in situ stable isotope enrichment experiment, the retention of nitrogen associated with sedimented planktonic material by a Mediterranean seagrass $\left(P\right.$. oceanica) meadow. ${ }^{15} \mathrm{~N}$-enriched algal material was injected into a meadow and nonvegetated sediment, and its fate was followed by monitoring the retention of the ${ }^{15} \mathrm{~N}$ label in the sediment and the appearance in $P$. oceanica roots, rhizomes, and leaves.

\section{Methods}

Study system - Lush P. oceanica meadows extend from 2 to $35 \mathrm{~m}$ depth in Magalluf Bay (Mallorca Island, Spain), where they grow under oligotrophic conditions on nutrientpoor carbonate sand (Holmer et al. 2003). The experiment was conducted during March 2002 at an area of the meadow $7 \mathrm{~m}$ deep $\left(39^{\circ} 30.23^{\prime} \mathrm{N}, 2^{\circ} 32.60^{\prime} \mathrm{E}\right)$ where unvegetated sand patches occur within the seagrass meadow (Fig. 1). The sediment at the study site is biogenic carbonate, dominated by coarse $(<0.5 \mathrm{~mm})$ and fine $(<0.125 \mathrm{~mm})$ sands, with a carbonate content of $>90 \%$ (Diaz del Rio et al. 1994).

In situ labeling experiment-An axenic clone of the diatom Amphora coffeaeformis (UTCC58, Toronto, Canada) was cultured in artificial seawater (F2) containing
$50 \%{ }^{15} \mathrm{~N}$-enriched nitrate. Diatoms were concentrated by centrifugation, washed several times to remove the ${ }^{15} \mathrm{~N}-$ $\mathrm{NO}_{3}$, and freeze-dried.

The retention of labeled materials was followed in the sediment and in the plant compartment with in situ experimental plots. The experiment was set up by first establishing 20 experimental plots (two habitats $\times$ five sampling events $\times$ two replicated plots per sampling event $=20$ plots). SCUBA divers established these plots by randomly inserting 10 polyvinyl chloride (PVC) cylinders into the sediments of a visually homogeneous area of the $P$. oceanica meadow, as well as in adjacent unvegetated sediments. Experimental plots were defined as the sediment contained inside these PVC cylinders, which were rigid, $18 \mathrm{~cm}$ in diameter, and inserted carefully with a hammer $10 \mathrm{~cm}$ into the sediment. To avoid the possible resuspension of material in the experimental plots, the experiment was initiated $1 \mathrm{~d}$ later by injecting ${ }^{15} \mathrm{~N}$-labeled algae into the sediment. The material was prepared by mixing $0.2 \mathrm{~g}$ of ${ }^{15} \mathrm{~N}$-labeled diatoms with $20 \mathrm{~mL}$ of filtered seawater, which was then injected with a glass syringe into the sediments. Four injections of $0.25 \mathrm{~mL}$ each were made to optimize label spreading in the experimental plot. In eight of the 10 PVC rings located in each habitat, label material was injected $5 \mathrm{~cm}$ deep into the sediment, the depth at which $P$. oceanica belowground material develops (Holmer unpubl. data). The remaining two plots in each habitat, which did not receive injections, were used as controls. The amount of labeled algae added was about $25 \mathrm{mg}^{15} \mathrm{~N} \mathrm{~m}^{-2}$, although the results show that some variability in the amount injected must have occurred among plots. These enclosures were sampled five times during the $21 \mathrm{~d}$ since the injection of the material in sediment under a $P$. oceanica meadow and adjacent unvegetated plot. Logistic constraints precluded sampling of the unvegetated experimental plots at $3 \mathrm{~d}$ after the injection. The disturbance of the plots in collecting plant and sediment material for analyses precluded the use of the same plot in subsequent sampling events, so two independent replicated plots were used for each habitat at each sampling time. An advantage of the use of different plots at each sampling event for each habitat is that they are truly independent, improving statistical analyses.

At each sampling event, a sediment core $(4.5 \mathrm{~cm}$ diameter) was collected from the area inside each PVC cylinder in each habitat, and $P$. oceanica material enclosed in each plot was harvested and separated into leaves, roots, and rhizomes to measure its labeled material. The leaf material was sorted into new (i.e., the youngest leaves within each shoot) and old material and analyzed separately. Youngest leaves were recognized as leaves without epiphytes, and old leaves (the remaining) were the leaves with epiphytes.

$\delta^{15} \mathrm{~N}$ determinations - The nitrogen isotopic composition of the sediments and plant material was determined with a Fisons elemental analyzer coupled online, via a Finnigan Con-flo 2 interface, with a Finnigan Delta $\mathrm{S}$ isotope ratio mass spectrometer (EA-IRMS). Nitrogen isotope ratios are expressed in the delta notation $\left(\delta^{15} \mathrm{~N}\right)$ relative to atmo- 
spheric nitrogen. The $\delta^{15} \mathrm{~N}$ reproducibility for both sediments and plants is about $0.3 \%$.

Excess ${ }^{15} \mathrm{~N}$ calculations-Excess ${ }^{15} \mathrm{~N}$ resulting from the addition of algae (excess $15 \mathrm{~N}$, E) was calculated as difference between the fraction $(\mathrm{F})$ of ${ }^{15} \mathrm{~N}$ of the control $F_{\text {control }}$ and the sample $F_{\text {sample }}, E=F_{\text {sample }}-F_{\text {control }}$, where $F={ }^{15} \mathrm{~N} /\left({ }^{15} \mathrm{~N}+{ }^{14} \mathrm{~N}\right)=\mathrm{R} /(\mathrm{R}+1)$. The nitrogen isotope ratio $(\mathrm{R})$ was derived from measured $\delta^{15} \mathrm{~N}$ values as $\mathrm{R}=$ $\left(\delta^{15} \mathrm{~N} / 1,000+1\right) \times \mathrm{R}_{\mathrm{atm}}$, with $\mathrm{R}_{\mathrm{atm}}=0.0036765$, the nitrogen isotope ratio of atmospheric nitrogen.

To compare the excess label material in the vegetated and unvegetated sediment compartment, we calculated the total excess ${ }^{15} \mathrm{~N}$ in the unvegetated sediment and in the $P$. oceanica compartment (seagrass tissues plus the integrated sediment below the seagrass meadow). The calculation of excess ${ }^{15} \mathrm{~N}$ in the plant compartment required the nitrogen content of seagrass tissues and the percentage of belowand aboveground parts. The nitrogen concentration of $P$. oceanica leaves (2.24\% dry weight) was derived from concurrent sampling on the same meadow investigated (Duarte unpubl. data), and data on the $\mathrm{N}$ concentration of rhizomes and roots were derived from Alcoverro et al. (2000). Average $( \pm$ SE) seagrass leaf biomass (332.49 \pm $41.84 \mathrm{~g} \mathrm{~m}^{-2}$ ) was derived from concurrent estimates of biomass in four replicate $0.025-\mathrm{m}^{2}$ plots (Barrón unpubl. data). The percentage of $P$. oceanica root, rhizome, and leaf biomass was derived from Mazzella et al. (1998). We assumed that new and old leaves account for $1 / 3$ and $2 / 3$ of the leaf biomass, respectively. Total ${ }^{15} \mathrm{~N}$ excess in sediments is reported as the depth-integrated $(0-15 \mathrm{~cm}){ }^{15} \mathrm{~N}$ excess $\left(\mathrm{m}^{-2}\right)$ of sediment and is calculated as the product of $\mathrm{E}\left({ }^{15} \mathrm{~N}\right.$ excess atom \%), measured sediment nitrogen content (wt \% $\mathrm{N}$ ), and a factor to convert dry weight units to volumebased units (1.6, on the basis of a sediment porosity of 0.6). Total ${ }^{15} \mathrm{~N}$ excess in seagrass $\left({ }^{15} \mathrm{~N}\right.$ excess $\mathrm{m}^{-2}$ of seagrass) was calculated from the product of plant $\mathrm{N}$ content per biomass unit, plant biomass $\left(\mathrm{m}^{-2}\right)$, and ${ }^{15} \mathrm{~N}$ excess atom $\%$ in plant tissues. Total ${ }^{15} \mathrm{~N}$ in the $P$. oceanica compartment is the sum of the seagrass tissues plus the integrated associated sediment below the seagrass meadow.

Statistical analyses-ANOVA and Tukey honestly significant difference (HSD) tests were used to compare the excess labeled particulates in the sediment under each habitat with depth and time since injection. A Wilcoxon ranked sign test was used to compare the excess labeled material in the different plant compartments analyzed and the excess labeled material between the $P$. oceanica system and unvegetated sediment. Least squares linear regression analysis was used to describe the temporal change in the ratio of excess material in the new leaves to roots along the experiment.

\section{Results}

An excess of labeled material in the unvegetated sediment was detected throughout the $21 \mathrm{~d}$ of the experiment (Fig. 2a). The excess the labeled particulates in the sediments ranged between $0.003 \pm 0.002$ and $0.13 \pm$
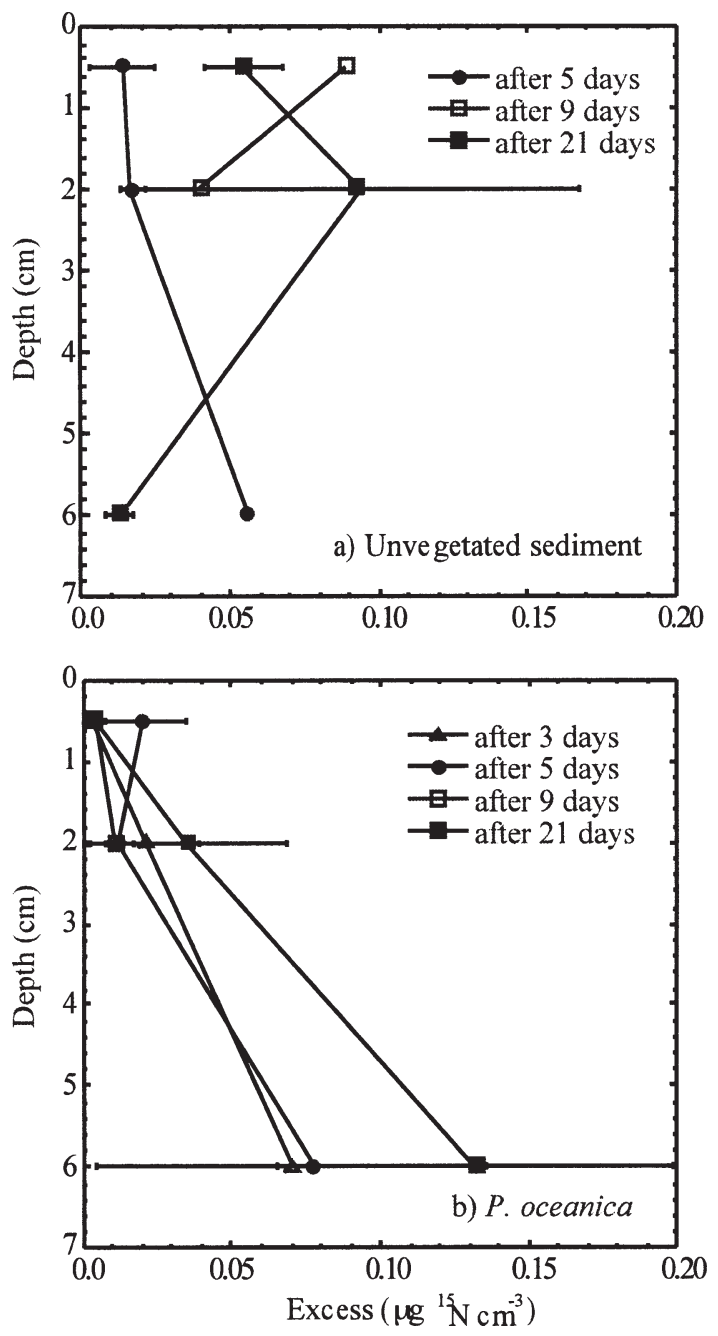

Fig. 2. Fate of the excess labeled material of ${ }^{15} \mathrm{~N}$ in the sediment $\left(\mu \mathrm{g}^{15} \mathrm{~N} \mathrm{~cm}^{-3}\right)$ from the (a) unvegetated and (b) vegetated incubations during the 21-d experiment. Average $\pm \mathrm{SE}$.

$0.07 \mu \mathrm{g}^{15} \mathrm{~N} \mathrm{~cm}^{-3}$. Maximal accumulation of the excess labeled material was found in the deeper part of meadow sediment with values higher than $0.07 \mu \mathrm{g}^{15} \mathrm{~N} \mathrm{~cm}^{-3}$ during the whole experimental period (Fig. 2b). The excess labeled particulate matter found in the sediment under the $P$. oceanica meadow and unvegetated sediment was independent (ANOVA $p>0.05$ ) of time since the injection of labeled material. However, in $P$. oceanica, the excess ${ }^{15} \mathrm{~N}$ particulates recovered in the cores differed significantly (ANOVA $p<0.01$ ) with depth in the sediments, with significantly more (Tukey HSD test $p<0.05$ ) labeled particles found in the deeper part of the sediment than at the surface and at $2 \mathrm{~cm}$ depth.

The excess labeled material in the rhizomes was significantly larger (Wilcoxon $p<0.05$ ) than that in the roots (Fig. 3a). The excess ${ }^{15} \mathrm{~N}$ in the roots and rhizomes reached a maximum at day 5 and then sharply decreased during the rest of the experimental period. The excess ${ }^{15} \mathrm{~N}$ in the rhizomes and roots at day 5 were $14.1 \pm 4.2$ and 6.2 $\pm 0.3 \mathrm{mg}{ }^{15} \mathrm{~N} \mathrm{~m}^{-2}$, respectively. This decrease in excess labeled material in roots and rhizomes was due to the 

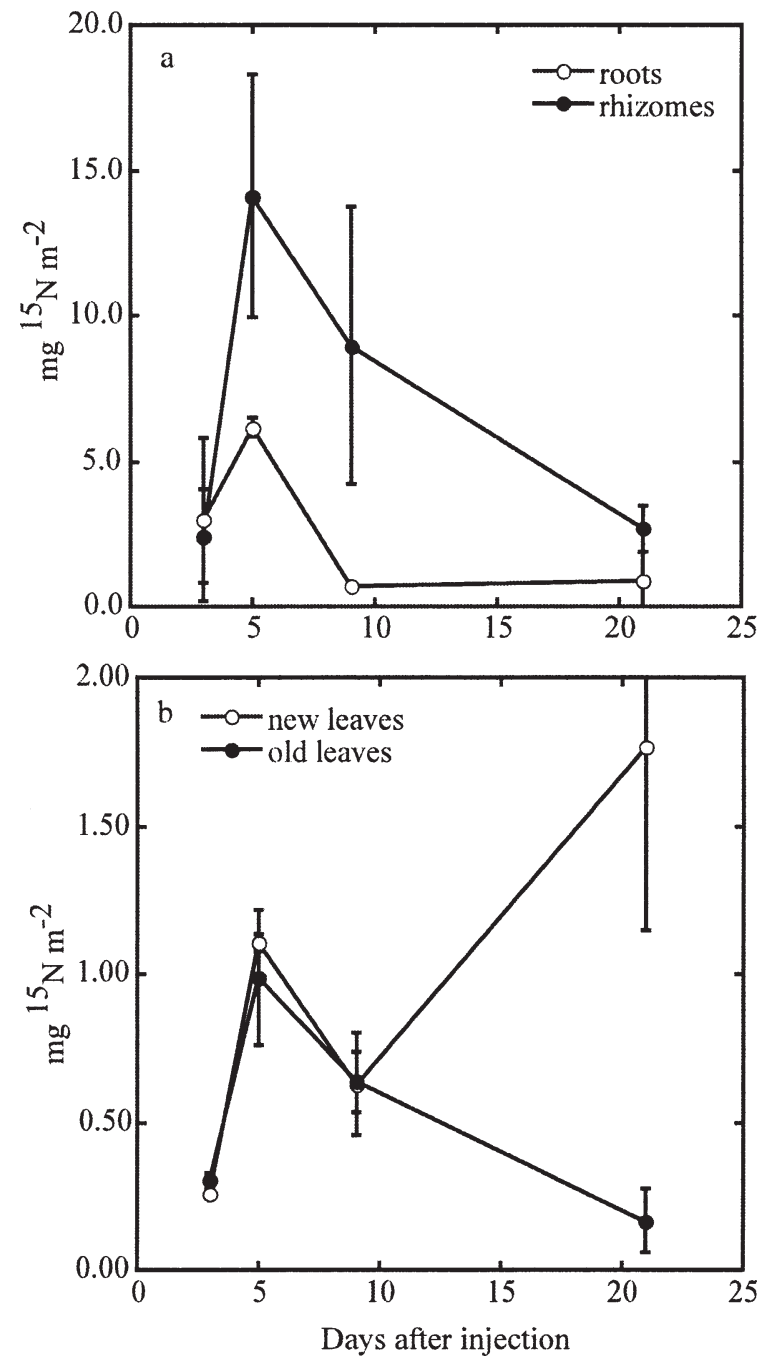

Fig. 3. Appearance of excess ${ }^{15} \mathrm{~N}\left(\mathrm{mg}^{15} \mathrm{~N} \mathrm{~m}^{-2}\right)$ in (a) the belowground parts of the $P$. oceanica (roots and rhizomes) and (b) the aboveground parts of the $P$. oceanica (new leaves and old leaves) collected from the benthic incubations during the 21$\mathrm{d}$ experiment. Average $\pm \mathrm{SE}$.

translocation of labeled nitrogen from the roots to the new leaves of the seagrass during the experimental period (Fig. 3b). This is evidenced by the significant increase ( $p<$ $0.01)$ in the ratios of excess labeled material in the new leaves relative to roots along the experiment (Fig. 4). Excess ${ }^{15} \mathrm{~N}$ in the old and new seagrass leaves were not significantly different during the first $10 \mathrm{~d}$ (Wilcoxon ranked sign test $p>0.05$ ), but after $21 \mathrm{~d}$, excess ${ }^{15} \mathrm{~N}$ in the new seagrass leaves exceeded that in the old leaves and reached a maximum of $1.8 \pm 0.6 \mathrm{mg}^{15} \mathrm{~N} \mathrm{~m}^{-2}$, whereas excess labeled material in the old leaves decreased to reach a minimum of $0.2 \pm 0.1 \mathrm{mg}^{15} \mathrm{~N} \mathrm{~m}^{-2}$ (Fig. $3 b$ ).

The excess labeled material in the $P$. oceanica ecosystem (sediment + plant compartment) during the whole experiment was significantly higher (Wilcoxon test $p<0.05$ ) than in the unvegetated sediment (Fig. 5), indicating that nitrogen retention was higher in the seagrass meadow than in bare sediments. The bulk ( $>80 \%)$ of the labeled material

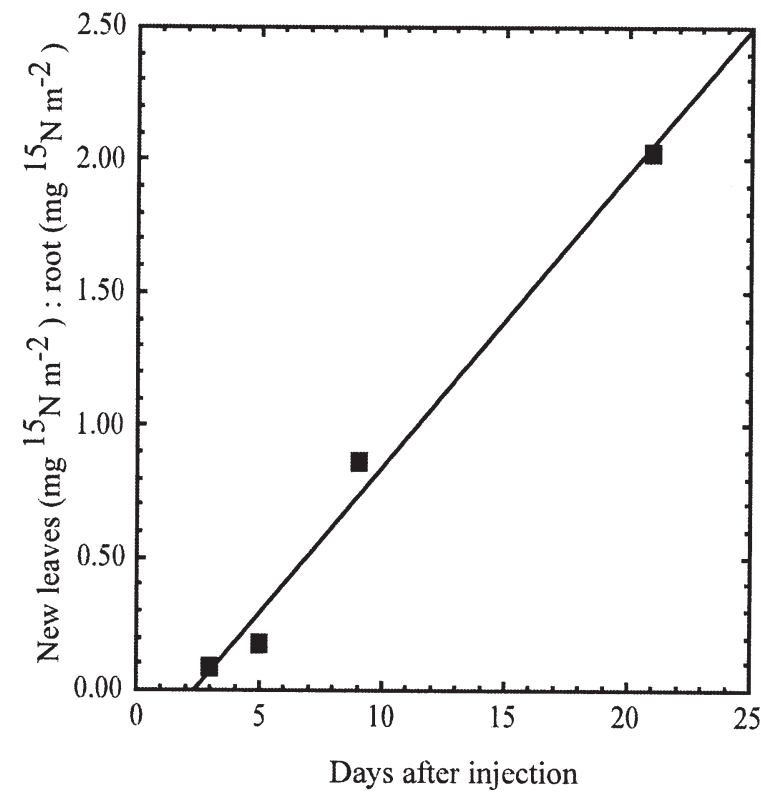

Fig. 4. Ratio of excess ${ }^{15} \mathrm{~N}$ in the new leaves to that in the roots of the seagrass $P$. oceanica during the 21-d experiment (average). Solid line represent the fitted linear regression equations: $15 \mathrm{~N}$ in the new leaves : ${ }^{15} \mathrm{~N}$ in the roots $=-0.25$ $( \pm 0.10)+0.11( \pm 0.01)$ days after injection, $r^{2}=0.98, p<0.01$.

added to the bare sediments (about $25 \mathrm{mg} \mathrm{N} \mathrm{m}^{-2}$ ) was lost within $5 \mathrm{~d}$ (Fig. 5), whereas $P$. oceanica meadows retained most of the labeled material, with the amount of labeled material retained in the $P$. oceanica meadow exceeding that in bare sediments fourfold on average (Fig. 5). Yet, the amount of labeled material retained within vegetated sediments did not differ significantly from that in bare sediments $(t$-test $p>0.05)$, so that the high retention in $P$. oceanica meadows can be attributed to capture of material

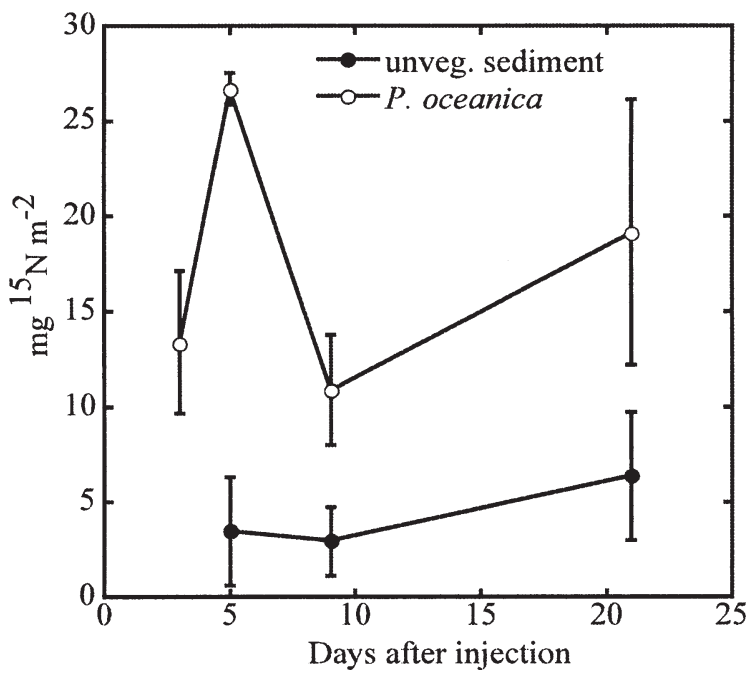

Fig. 5. Fate of the excess labeled material $\left(\mathrm{mg}^{15} \mathrm{~N} \mathrm{~m}^{-2}\right)$ in the integrated sediment under the unvegetated benthic (unveg. sediments) community and in the $P$. oceanica compartment (seagrass tissues + the integrated associated sediment below the seagrass meadow). Average $\pm \mathrm{SE}$. 
by the plant, which contained on average about $67 \%$ of the label retained during the experiment.

\section{Discussion}

The experiment showed that the $P$. oceanica meadow investigated tended to be very efficient in acquiring and retaining the nitrogen associated with deposited algal material. Although the pool of labeled material should have been highest at the onset of the experiment, the excess ${ }^{15} \mathrm{~N}$ was variable, perhaps because of heterogeneity of initial label addition and distribution or the homogenization of the material within the sediments with time. The variability in excess $\mathrm{N}$ in $P$. oceanica might not only be attributed to variability in the amount of tracer supplied among plots but also to different retention rates among plots because $P$. oceanica biomass, and therefore retention capacity, showed substantial patchiness in the meadow (coefficient of variation of $P$. oceanica biomass, 20\%). Hence, the differential retention capacity is attributable to the plant's capacity to retain the remineralized nitrogen that would otherwise be lost to the water column.

The labeled material in the $P$. oceanica communities remained deeper in sediments than that added to the unvegetated sediment. The longer residence of ${ }^{15} \mathrm{~N}$ at depth in seagrass meadow sediments suggests a higher retention of particles by the thick rhizomes that network seagrasses develop. The bulk of the root biomass in $P$. oceanica was situated between 2 and $8 \mathrm{~cm}$ deep in the sediment (Holmer unpubl. data). Moreover, $P$. oceanica meadows support benthic fauna that contribute to particulate organic matter burial (e.g., rapid burial of surface-deposited organic matter into the sediment by the burrowing shrimp Pestarella tyrrhena; Papaspyrou et al. 2004).

On an annual scale, $72 \%$ of the sedimentary carbon flux under a $P$. oceanica meadow was derived from sestonic particles, and the remaining came from detritus of $P$. oceanica and its associated epiphytes (Gacia et al. 2002). Thus, $P$. oceanica contributes to the trapping of particles from the water column (Duarte et al. 1999; Agawin and Duarte 2002). The trapping effect of seagrass canopies is not only restricted to sediment particles suspended in the water, but it also affects organic particles such as phytoplankton and detritus. Around $40 \%$ of the vegetated sediment carbon was of planktonic origin (Kemp et al. 1984), and direct trapping of planktonic particles by seagrass canopies is evident (Agawin and Duarte 2002). Hence, the trapping process is an efficient mechanism for the transfer of planktonic production to the benthos (Agawin and Duarte 2002). Moreover, the deposited material is retained more efficiently in the sediment because $P$. oceanica leaf canopies reduce particle resuspension (Terrados and Duarte 2000; Gacia and Duarte 2001).

Our results showed that the labeled material in the sediment was retained throughout the experiment and was, therefore, available to supply nutrients to the seagrass. The fast $\mathrm{N}$ uptake by seagrass might not require complete remineralization of the organic material added because some plants have been shown to be able to use organic monomers released by microbial extracellular enzymes
(Schimel and Bennett 2004), a potential not yet tested for $P$. oceanica. Moreover, the release of organic label material from the belowground or aboveground compartment could also not be tested with this experiment. However, in situ benthic communities dominated by Cymodocea nodosa (Barrón et al. 2004) and Thalassia testudinum (Ziegler and Benner 1999) released dissolved organic matter to the surrounding water.

Seagrasses that live in environments with low nutrient concentrations are able to obtain nutrients from the surrounding water by the leaves well as well as by the roots (Hemminga et al. 1991; Lee and Dunton 1999), so the appearance of label in the above- and belowground parts of $P$. oceanica could indicate direct uptake by these two compartments. However, label appeared first in the belowground organs and was then transferred to aboveground tissue (Fig. 4) to reach the leaves and ultimately be transferred to new leaves, where it appears to accumulate. This leads to substantial storage of the added N, thereby helping to retain it with an efficiency more than four times that in unvegetated sediments. Indeed, leaves are usually the major sink for nutrient in seagrasses (Hemminga et al. 1999). The lack of evidence of storage of $\mathrm{N}$ roots and rhizomes is consistent with tissue $\mathrm{N}$ concentrations $<2 \%$ (dry weight), which is the level considered to indicate Nsufficient plants (Duarte 1990). For eelgrass, the N acquired by old seagrass leaves is rapidly transferred to young ones, consistent with the patterns observed here (Borum et al. 1989; Pedersen and Borum 1992). The translocation of nutrients from old to new leaves has been calculated to supply $40 \%$ of the annual nitrogen requirements of P. oceanica (Alcoverro et al. 2000; Lepoint et al. 2002).

The presence of seagrasses led to a greater retention of labeled material than that observed in unvegetated sediments because much of the remineralized material was captured and accumulated in new leaves by the seagrass. White and Howes (1994) enriched vegetated sediment in a salt marsh with ${ }^{15} \mathrm{NH}_{4}^{+}$and $100 \mathrm{~d}$ after the injection $<7 \%$ of the ${ }^{15} \mathrm{~N}$ was present in the inorganic ammonium pool and the remainder was in the living and dead plant material. The sequence of processes affected by the seagrass starts with enhanced sediment deposition and retention (Kemp et al. 1984; Ward et al. 1984; Agawin and Duarte 2002), followed by enhanced mineralization (e.g., Hemminga and Duarte 2000; Holmer et al. 2003) and plant uptake of the released nutrients. This is an efficient mechanism to sustain high seagrass productivity in oligotrophic waters (Evrard et al. 2005). The net result of these processes is a capacity to sequester nutrients from seston, which might contain a large fraction of the total nutrient pool in oligotrophic ecosystems. This could confer seagrass a competitive advantage over other primary producers in such environments. The development of dense seagrass canopies, such as those in $P$. oceanica beds, is essential to the process because it enhances trapping of sestonic materials and provides the biomass needed to store them for seagrass use. 


\section{References}

Agawin, N. S. R., And C. M. Duarte. 2002. Evidence of direct particle trapping by a tropical seagrass meadow. Estuaries 25: $1205-1209$.

Alcoverro, T., M. Matanza, and J. Romero. 2000. Nutrient mass balance of the seagrass Posidonia oceanica: The importance of nutrient retranslocation. Mar. Ecol. Prog. Ser. 194: 13-21.

, J. Romero, C. M. Duarte, And N. I. López. 1997. Spatial and temporal variations in nutrient limitation of seagrass Posidonia oceanica growth in the NW Mediterranean. Mar. Ecol. Prog. Ser. 146: 155-161.

Barrón, C., N. Marbà, J. Terrados, H. Kennedy, and C. M. DuARTE. 2004. Community metabolism and carbon budget along a gradient of seagrass (Cymodocea nodosa) colonization. Limnol. Oceanogr. 49: 1642-1651.

Borum, J., L. Murray, and W. M. Kemp. 1989. Aspects of nitrogen acquisition and conservation in eelgrass plants. Aquat. Bot. 35: 289-300.

Brix, H., And J. E. Lyngby. 1985. Uptake and translocation of phosphorus in eelgrass (Zostera marina). Mar. Biol. 90: 111-116.

Diaz del Rio, V., L. Somoza, J. L. Goy, C. Zazo, J. Rey, F. J. Hernández-Molina, And G. Mateu. 1994. Mapa Fisiográfico de la Bahía de Palma. Publicaciones Especiales del Instituto Español de Oceanografía. 16: 39.

Duarte, C. M. 1990. Seagrass nutrient content. Mar. Ecol. Prog. Ser. 67: 201-207.

. 1995. Submerged aquatic vegetation in relation to different nutrient regimes. Ophelia 41: 87-112.

- E. Benavent, and S. M. D. C. SÁnchez. 1999. The microcosm of particles within seagrass Posidonia oceanica canopies. Mar. Ecol. Prog. Ser. 181: 289-295.

- AND J. CEBRiÁn. 1996. The fate of marine autotrophic production. Limnol. Oceanogr. 41: 1758-1766.

$\longrightarrow$, And C. L. Chiscano. 1999. Seagrass biomass and production: A reassessment. Aquat. Bot. 1334: 1-16.

- J. J. Middelburg, And N. CARAco. 2005. Major role of marine vegetation on the oceanic carbon cycle. Biogeosciences 1: $173-180$

Evrard, V., W. Kiswara, T. J. Bouma, and J. J. Middelburg. 2005. Nutrient dynamics of seagrass ecosystems: ${ }^{15} \mathrm{~N}$ evidence for the importance of particulate matter and root systems. Mar. Ecol. Prog. Ser. 295: 49-55.

Gacia, E., And C. M. Duarte. 2001. Sediment retention by a Mediterranean Posidonia oceanica meadow: The balance between deposition and resuspension. Estuar. Coast. Shelf Sci. 52: 505-514.

, deposition in the Mediterranean seagrass (Posidonia oceanica). Limnol. Oceanogr. 47: 23-32.

—, T. C. Granata, and C. M. Duarte. 1999. An approach to measurement of particle flux and sediment retention within seagrass (Posidonia oceanica) meadows. Aquat. Bot. 65: 255-268.

Gattuso, J.-P., M. Frankignoulle, and R. Wollast. 1998. Carbon and carbonate metabolism in coastal aquatic ecosystems. Ann. Rev. Ecol. Syst. 29: 405-434.
Hemminga, M. A., And C. M. Duarte. 2000. Seagrass ecology. Cambridge Univ. Press.

- P. G. Harrison, and F. van Lent. 1991. The balance of nutrient losses and gains in seagrass meadows. Mar. Ecol. Prog. Ser. 71: 85-96.

— N. Marbà, AND J. Stapel. 1999. Leaf nutrient resorption, leaf lifespan and the retention of nutrients in seagrass systems. Aquat. Bot. 65: 141-158.

Holmer, M., C. M. Duarte, And N. Marbà. 2003. Sulfur cycling and seagrass (Posidonia oceanica) status in carbonate sediments. Biogeochemistry 66: 223-239.

Kemp, W. M., W. R. Boynton, R. R. Twilley, J. C. Stevenson, AND L. G. WARD. 1984. Influences of submersed vascular plants on ecological processes in upper Chesapeake Bay, p. 367-394. In V. Kennedy [ed.], The estuary as a filter. Academic.

LeE, K.-S., And K. H. Dunton. 1999. Inorganic nitrogen acquisition in the seagrass Thalassia testudinum: Development of a whole-plant nitrogen budget. Limnol. Oceanogr. 44: $1204-1215$.

Lepoint, G., O. Defawe, S. Gobert, P. Dauby, and J.-M. BouQuegNEAU. 2002. Experimental evidence for $\mathrm{N}$ recycling in the leaves of the seagrass Posidonia oceanica. J. Sea Res. 48: $173-179$.

Mazzella, L., AND others. 1998. Biomass partitioning in Adriatic seagrass ecosystems (Posidonia oceanica, Cymodocea nodosa, Zostera marina). Rapp. Comm. Int. Mer Méditerr. 35: $562-563$.

Papaspyrou, S., M. Thessalou-Legaki, and E. Kristensen. 2004. Impact of Pestarella tyrrhena on benthic metabolism in sediment microcosms enriched with seagrass and macroalgal detritus. Mar. Ecol. Prog. Ser. 281: 165-179.

Pedersen, M. F., ANd J. Borum. 1992. Nitrogen dynamics of eelgrass Zostera marina during a late summer period of high growth and low nutrient availability. Mar. Ecol. Prog. Ser. 85: $65-73$.

Schimel, J., AND J. BennetT. 2004. Nitrogen mineralization: Challenges of a changing paradigm. Ecology 85: 591-602.

Short, F. T., AND C. P. McRoy. 1984. Nitrogen uptake by leaves and roots of the seagrass Zostera marina L. Bot. Mar. 27: $547-555$.

Terrados, J., And C. M. Duarte. 2000. Experimental evidence of reduced particle resuspension within a seagrass (Posidonia oceanica L.) meadow. J. Exp. Mar. Biol. Ecol. 243: 45-53.

Ward, L. G, W. M. Kemp, and W. R. Boynton. 1984. The influence of waves and seagrass communities on suspended particulates in an estuarine embayment. Mar. Geol. 59: 85-103.

White, D. S., ANd B. L. Howes. 1994. Long-term ${ }^{15} \mathrm{~N}$-nitrogen retention in the vegetated sediments of a New England salt marsh. Limnol. Oceanogr. 39: 1878-1892.

Ziegler, S., AND R. Benner. 1999. Dissolved organic carbon cycling in a subtropical seagrass-dominated lagoon. Mar. Ecol. Prog. Ser. 180: 149-160.

Received: 22 February 2005 Accepted: 11 October 2005 Amended: 12 January 2006 